\title{
TECHNICAL ASPECTS CONCERNING A ROBOT USED FOR CHECKING THE SEWER PIPES
}

\author{
Daniel Popescu, Dan Sever Ionescu \\ Faculty of Building Services and Equipment, Technical \\ University of Civil Engineering Bucharest (UTCB), 66, \\ Pache Protopopescu Blvd., 021414 Bucharest, Romania \\ dpopescu@instal.utcb.ro
}

\author{
Adrian Bruja \\ Research Institute for Equipment and \\ Technologies in Civil Engineering Bucharest \\ (ICECON), 266, Pantelimon Blvd. 021652 \\ Bucharest, Romania \\ bruja@utcb.ro
}

\begin{abstract}
The work shows the principles and techniques that were the base of conceiving the control equipment to drive the robot mechanism, to align the video camera used for the checking of the pipe and the way of taking over the video images on a computer. The driving of the robot moving system is done by means of direct current electric motors. The power supply and the robot's controls are provided by means of an electric cable. The positioning of the video camera in the field of images taking is done by operator through a joystick. The human operator can monitor the position of the video camera by means of an indicator optic system realized with LED. The video images loaded in a computer memory have attached information about the pipe visited, the robot position into the pipe, data, the hour of inspection and will make reports about the sewer pipes state.
\end{abstract}

Keywords: Check the sewer pipes, Control equipment, Control of video camera.

\section{INTRODUCTION}

The robot is intended to check the sewer pipes on maximal lengths of $50 \mathrm{~m}$. The diameters of the pipes can be included between $300 \mathrm{~mm}$ and $1000 \mathrm{~mm}$.

The robot has been conceived and experienced within a national research program in Romania.

The driving of the robot moving system is done by means of direct current electric motors, mechanical reducers and electromagnetic couplers. The power supply and the robot's controls are provided by means of an electric cable that connects the robot in the pipe at the control and supply board. The signal of the video camera is brought by a separate cable at the video capture plate in the images processing computer.

The moving ahead and back of the robot through the pipe can be done with normal or reduced speed. By controlling the motors and electromagnetic couplers the robot can move, can stay in a firm position, or in case of disturbance, the recover from pipe can be allowed by dragging.

The positioning of the video camera in the field of image taking is done by operator through a joystick by which one remotes control the alignment device of the video camera on two freedom degrees, having as reference the horizontal plane, reference secured by means of a gyroscope system. The human operator can monitor the position of the video camera by means of an optical indicator system realized with LED's. It is able to indicate the alignment of the camera in any of the four scales, on any axle, or in the origin of the coordinates system. The control sequence automatic machine of the optical system is synthesized using specific procedures.

The position of the video camera is defined by means of arresting devices. These are located, in order to detect its extreme allowed positions. There are also two sensitive devices (detectors) that settle the positioning on the axle of the pipe.

The video camera can be aligned self-acting on the pipe's axle, (in the origin of the axles) by an independent action.

\section{ROBOT'S COMPONENT PARTS}

The robot for sewer pipes inspection has the following important components (fig. 1):

A. Inspection robot

A1. The video head mechanism, on which are placed, the video camera, the light bulb for lightning the area of image retrieving, and the DC motors for rotating the video camera in horizontal and vertical plane and the positioning micro-switches.

A2. The moving ahead and back mechanism of the robot into the pipe.

B. Control and instrument board

C. Robot's connection cable to the Control and instrument board rolled on a winch.

D. Control panel on which is placed the joystick for video head orientation.

E. Portable computer (laptop).

F. Video capture system (Video capture card of retrieved images from the interior of the pipes).

G. Power generator.

Electrical connections between the components are done thru the electric wiring.

The transportation of the robot to the inspection area is made with a specially designed vehicle. The control and instrument board and the control panel will be used from the inside of the vehicle. 


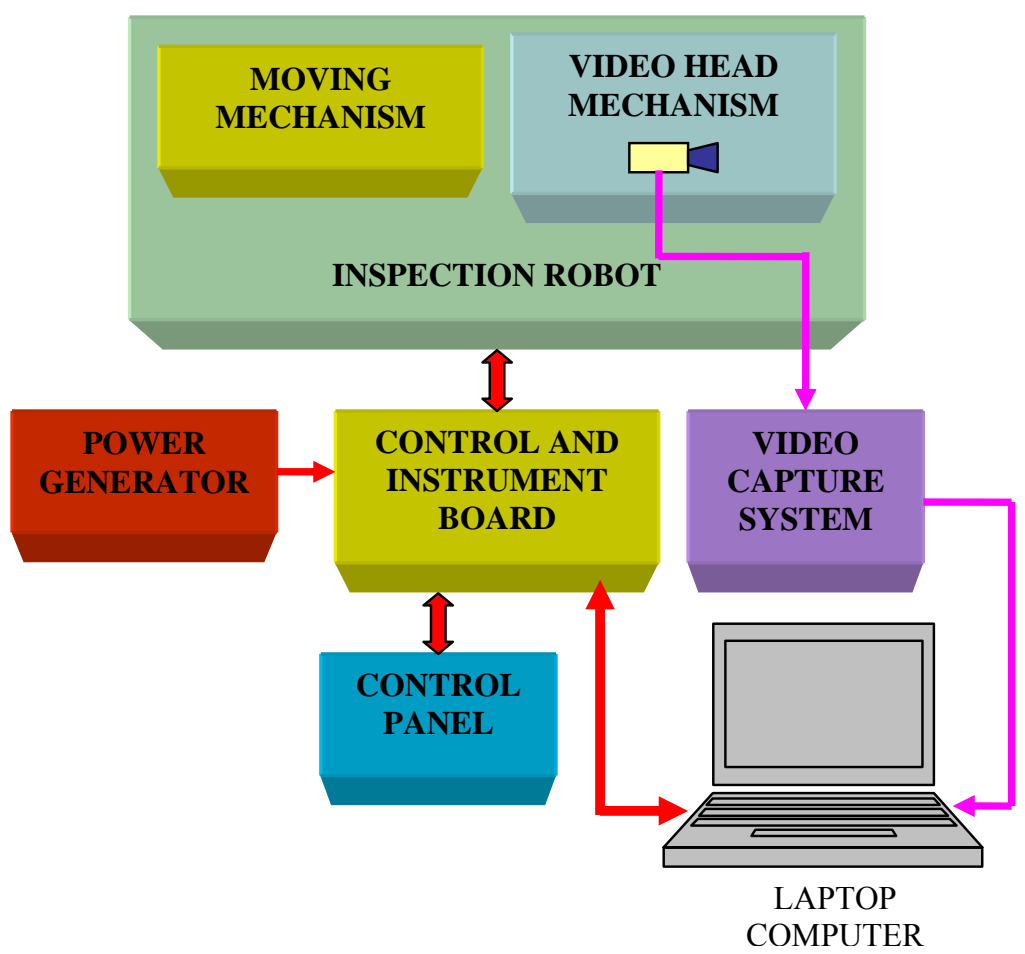

Figure 1. Main component parts of the robot.

\section{AUTOMATIC CONTROL SYSTEM OF THE ROBOT}

The automatic control system of the robot is composed of:

- Command equipment (placed in the control and instrument board);

- Data measuring and acquisition system (placed in the control and instrument board);

- Position transducers of the robot and video head mechanism (placed in the robot);

- Temperature and humidity sensors (placed in the robot);

- Working elements for moving mechanism of the robot and video camera positioning mechanism.

For the operator's ease of use we've made the control panel separately from the control and instrument board; The joystick and the optical system with LED's for showing the video camera position, are placed both on a small mobile control panel linked to the control and instrument board thru a cable.

\subsection{Block Diagram}

Block diagram of the automatic control system is presented in figure 2 . The diagram is organized to pointout the main automation equipment which is data acquisition and control system [1,2,3]. The system is made with a microcontroller with input and output interfaces to which the devices of the robot are connected, manual control and also the computer for image retrieving and storing.

Placing of the diagram components is the following:

- The microcontroller for data acquisition and process control in the control and instrument board;

- Command buttons, command keys, the joystick, in the control panel;

- Optical signaling of robot's state and indication of the video head position, , in the control panel and in control and instrument board;

- Motors for robot movement, and electromagnetic clutches, on the robot's moving mechanism;

- Motors for video camera positioning, logical sensors and halogen light bulb in the video head mechanism.

Video camera is connected to the video capture system $[3,4]$, connected to the computer thruough a special cable. This cable is separated from the electrical multi wiring cable which provides the electrical power and linkage to the control commands of the sewerage pipes inspection robot the two cables are fixed together and are rolled on the same drum.

\subsection{Operation}

In figure 3 is presented an assemble picture of the robot together with the Control panel on which the experiments were made.

The operation of the automation control system is independent from the operation of the video camera, of the capture system and the computer [2,3]. 


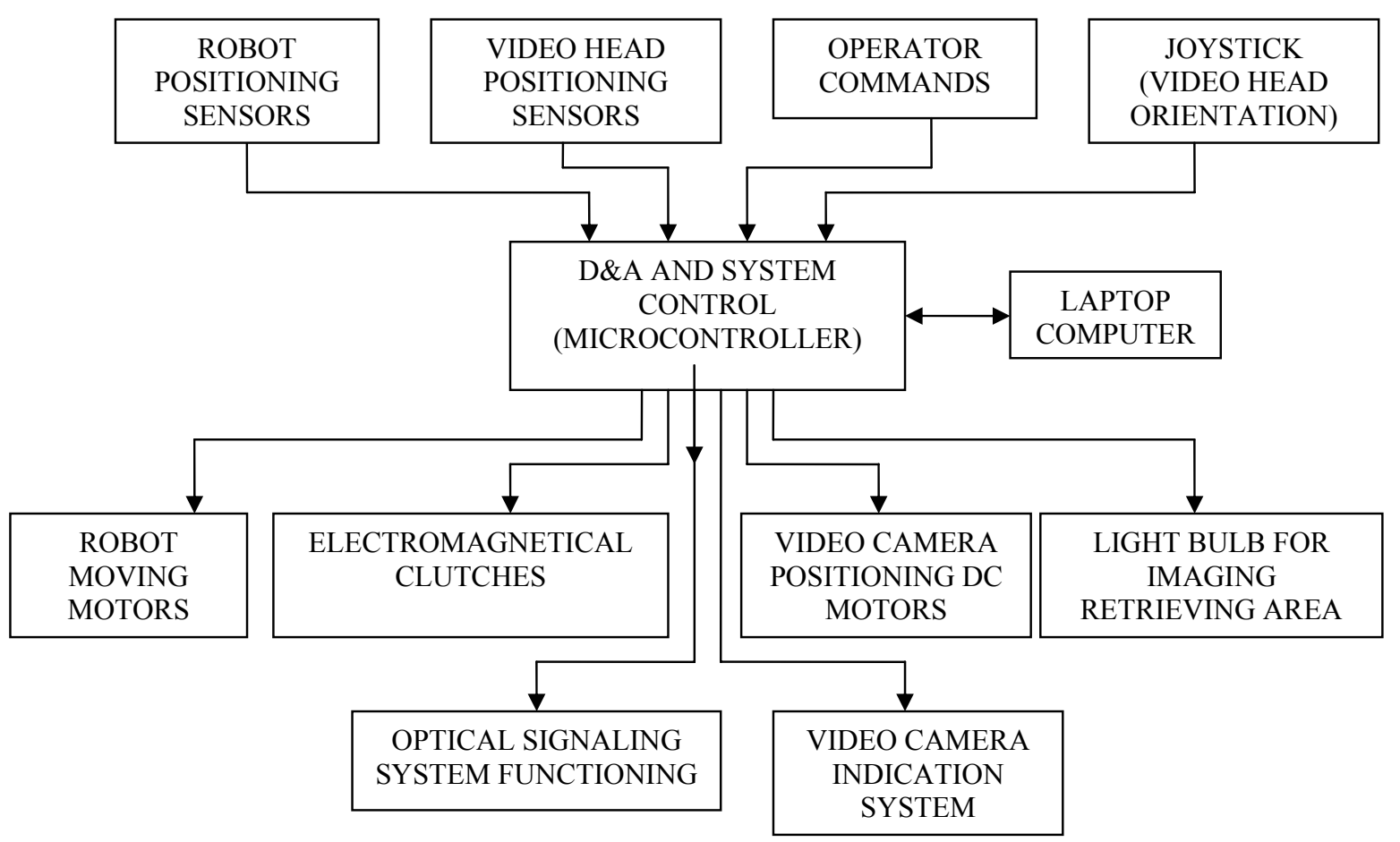

Figure 2. Block diagram of automatic system of robot control.

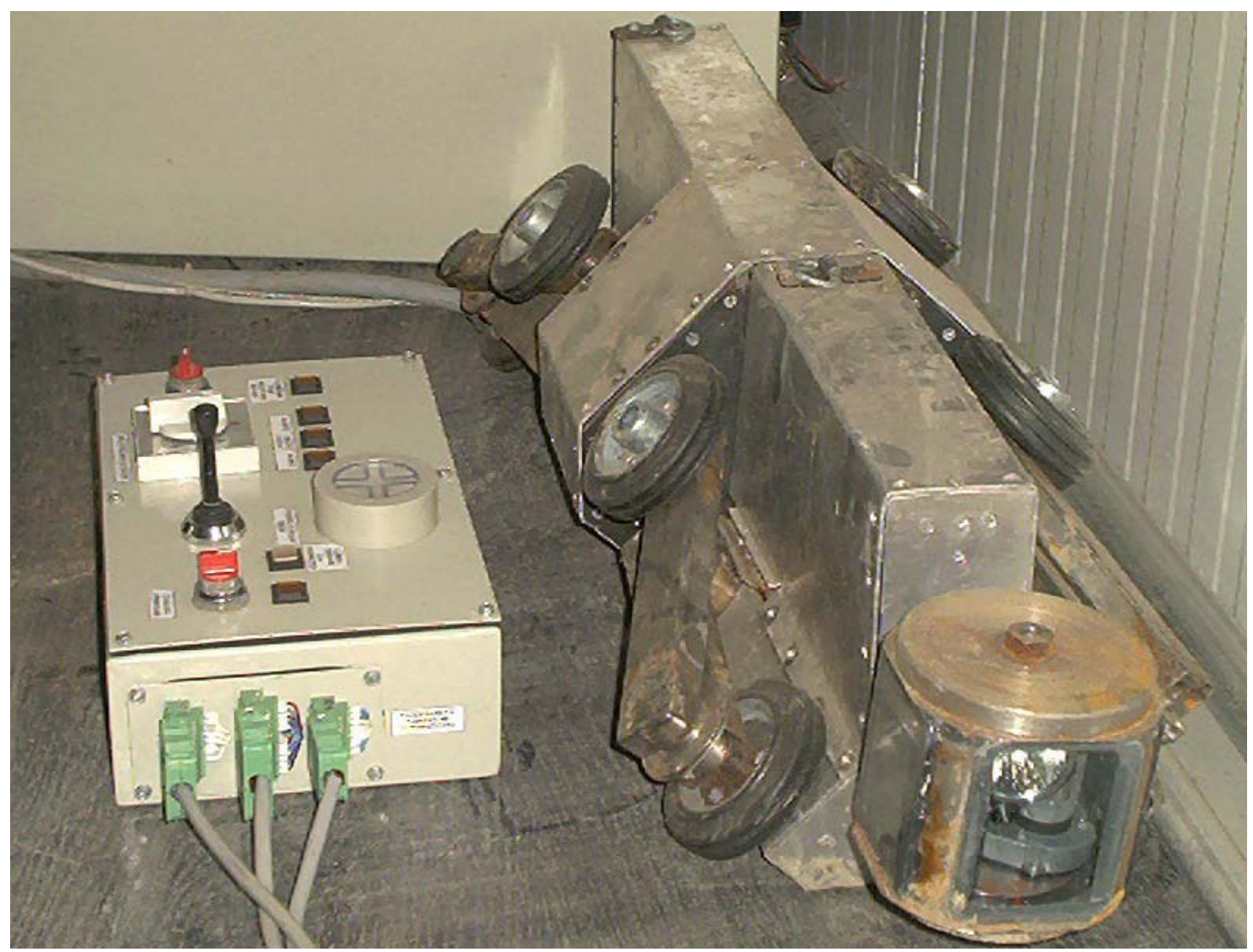

Figure 3. View of robot assembly. 
Taking into account the operation conditions of the robot (along the sewerage pipes), Electrical power of $230 \mathrm{~V}$, $50 \mathrm{~Hz}$ is obtained from a portable power generator or, when it's possible from the low voltage networks of the energetic system.

The inspection robot is introduced manually into the pipe and after that the robot is adapted to the dimensions of the pipe $[2,6]$. This moment, the robot is able to move in the sewer pipe with the electrical motors.

The operator watches on the computer monitor the retrieved images and proceeds to operate the robot into the pipe, or to the positioning the video camera by necessity. Going forward and backward can be done with low speed or high speed.

Positioning of the video camera is done with 2 direct current motors. The system has 2 Degrees of freedom in which the local horizontal plane is obtained by means of a gyroscopic system and which is the reference plane [6,7].

To easily orient the video camera in the retrieving area, the operator has an optical system with LED's that indicates the position of the video head [2,3,5]. The indicated position is in the X-Y plane explored by the video camera.

If the robot gets damage in the pipe, it can be dragged manually, after the clutches have been released from the moving mechanism.

The software for processing and storing the retrieved images from the pipe is default, from the moment the operator initiates the inspection $[4,5]$.

\subsection{Implementing the logical program}

Automatic control system was designed starting from the functional requirements. The set of logical equations was planned after watching the process to be programmed $[1,5]$; the program was written in microcontroller level. Here have been designed the acquisition and measuring system of length advance of the robot in the pipe, temperature, and humidity from within the pipe $[3,4]$. In this phase of the work the protocol of data acquisition and command is done on separate lines in simplex system. The program takes care for the self testing of the system, while in operation.

\section{ACQUISITION AND PROCESSING OF IMAGES}

Acquisition and processing system has an added feature of marking in real time the inspection's main data retrieved from the acquisition and measuring system $[3,4]$.

\section{CONCLUSIONS}

Experimental results obtained during tryouts indicate that it is necessary to include in the processes of inspection of the sewerage pipes the implementation of the robot from installation of the pipes and during the life of exploitation.

Although the cable link allows salvaging the robot in case of malfunction, this method is limiting the inspection distance and makes difficult robot operation during winter because of the high rigidity of the cable. Currently it is under study another design of a wireless robot with autonomous power source.

\section{REFERENCES}

[1] Bruja, A., Dima, M. - « Robot porteur d'équipements pour finissage dans le domaine des constructions RFC-10 » Analele Universitătii "Dunărea de Jos" Galați, Fascicola XIV, pag. 113-118, ISSN 1224-5615, Brăila, Romania, 2001.

[2] Bruja, A., Dima, M. - «Lés mécanismes de positionnement et d'orientation d'un robot pour finissages en constructions » IX International Conference on the Theory of Machines and Mechanisms, 31.08 - 02.09.2004 Liberec, Cehia, ISBN 80-7083-847-7, pag 147-152.

[3] Bruja, A., Dima, M. - „Manipulator telecomandat pentru vizitare şi întreținere conducte de canalizare" Culegerea de articole ale Conferinței tehnico-ştiințifice internaționale pe probleme actuale ale urbanismului, Chişinău, Republica Moldova, 14-15 noiembrie 2002, vol. II, pag. 406-412.

[4] Bruja, A., Dima, M. Popa, S.- „Remote controlled mobile module for sewer pipes inspection" Buletinul ştiințific al celei de-a 26 Conferinte Naționale de Mecanica Solidelor a Acadedemiei de Ştiințe Tehnice din România, Brăila 14-15 iunie 2002, pag. 379-384.

[5] Bruja, A., Dima, M., Moraru, L. - «Manipulateur télécommandé pour le nettoyage des surfaces vitrées » Articol, Buletinul ştiințific al celei de-a 26 Conferinte Naționale de Mecanica Solidelor a Acadedemiei de Ştiințe Tehnice din România, Brăila 14-15 iunie 2002, pag. 373378.

[6] Bruja, A., Dima, M., Moraru, L. - «L'étude cinématique et cinétostatique du mécanisme de déplacement de l'équipement pour finissage pour le robot RFC - 10 » Analele Universitătii "Dunărea de Jos" Galați, Fascicola XIV, pag. 113-118, ISSN 1224-5615, Brăila, Romania, 2001.

[7] Bruja, A., Dima, M. - „Remote controled manipulator for cleaning vitrate surfaces" Culegerea de articole ale Conferinței tehnico-ştiințifice internaționale pe probleme actuale ale urbanismului, Chişinău, Republica Moldova, 14-15 noiembrie 2002, vol. II, pag. 413-417. 